\title{
Problems of Effectiveness of Education Services for Persons with Disabilities in the Russian Federation
}

\author{
Elena Khudorenko ${ }^{1}$ \\ ${ }^{1}$ Ph.D. in Political Science, Associate Professor, Department of World Economy and In- \\ ternational Relations, Moscow State University of Economics, Statistics, and Informatics
}

\begin{abstract}
Education for Persons with Disabilities is a special socio-economic resource which is of paramount importance, aimed at reducing their isolation and economic dependence. The article is devoted to investigating the problems of effectiveness of educational services for persons with disabilities and possible ways of solving them.
\end{abstract}

Keywords: economic effectiveness, education service, indicators of performance, smart economy, education of persons with disabilities, employment indicators for persons with disabilities, development of social consciousness, global financial crisis, forms of learning of persons with disabilities, level of professional qualification, the un convention on rights of persons with disabilities, inclusive education, education without discrimination

\section{Introduction}

Educational services as a public good are characterized by joint nature of consumption, indivisibility, causing significant external positive effect, which is reflected in high rates of productivity and economic growth, enhancing social stability and competitiveness of national economy. Thus, effectiveness of educational services and their quality have an impact on the structure of modern labor, contribution to GDP, and, consequently, on the quality of life. This is especially important for people with disabilities, for whom low availability of educational services and low demand in the Russian labor market lead to declining of individual and national productivity as well as to inefficient use of human capital in general.

\section{Effectiveness of educational services for persons with disabilities}

\subsection{Employment indicators for persons with disabilities}

According to Deputy Chairman of the State Duma Committee on Education O. Smolin, limiting access to self-realization for persons with disabilities in the Russian Federation leads to a loss of five to seven percent of GDP. [1]

According to statistics, only 5\% of disabled people of working age have an opportunity to work in their professional area. [2] The others work on a "I will work where I will be needed" term. Chairman of the All-Russian Society of Disabled People, deputy of the State Duma of the Russian Federation A. Lomakin-Rumyantsev considers that people with disabilities are recruited only on non-prestigious, low-skilled positions with low salaries. [3]

According to research conducted by the Russian scientists E. YarskayaSmirnova and P. Romanov, only $16.4 \%$ of disabled persons with diplomas of 
higher education are working on jobs that require higher education. [4].

\subsection{Factors determining employ- ment process for persons with disabili- ties}

There are several groups of factors that affect the process of employment for persons with disabilities in the Russian Federation.

The first group of factors is determined by underdevelopment of social consciousness of Russians. As a result, there is no fundamental change in perception of people with disabilities as equal to others category of citizens of the Russian state. Meanwhile, the Convention on the Rights of Persons with Disabilities, signed by Russia in September, 2008, introduces common for all countries basic concepts primarily related to all to definitions of "disability" and "disabled". According to the preamble (paragraph " $\mathrm{e}$ " of the Convention), "disability is an evolving concept and disability is the result of interaction between persons with impairments, attitudinal and environmental barriers which hinder their full and effective participation in society on an equal basis with others ..." [5].

One of the reasons for weakness of the labor market of people with disabilities is lack of legal regulation of employment of persons with disabilities. [6] Ideally, legal regulation has to ensure that every able-bodied person with disability is employed in accordance with his/her professional skills, capabilities, and needs. But it's so far from reality. For example, quota system for employment of persons with disabilities in small and mediumsized enterprises is mostly eliminated [7].

The following data shows the number of disabled people in the Russian Federation employed via quotas for the time period of 2000 - 2007. [7]

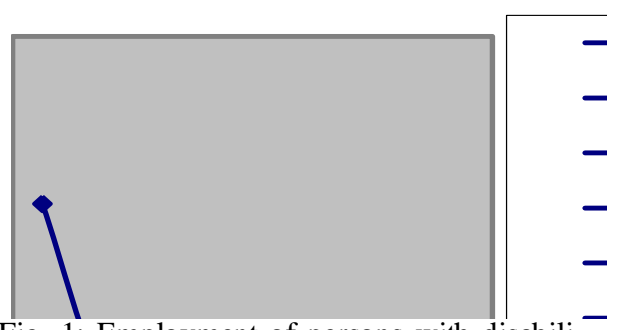

Fig. 1: Employment of persons with disabilities by employment quotas in 2000-2007

Another negative point having a negative impact on the level and quality of employment of persons with disabilities is collapsing of active measures to create a barrier-free living environment for people with disabilities in many Russian regions. As a result, there was a reduction in funding of regional programs for persons with disabilities, including programs aimed at ensuring employment of disabled people of working age in the Russian Federation.

Another reason for funding cuttings in regional and federal programs on employment of persons with disabilities was world financial crisis and associated with it reducing financial support of companies that employ people with disabilities. The global financial crisis has led to a decrease of economic activity, contributed to jobs loss, reduction of wages, and slow down in the process of creating new jobs.

"The reduction in public spending may affect the operation of systems of healthcare, education, and social insurance, further limiting already low level of access to social services to people with disabilities - say representatives of the World Bank. - In addition, the cuts could prevent - or will force to completely stop - the implementation of measures aimed at improving the access of disabled to public buildings and other infrastructure, which is an important factor, contributing to integration of disabled persons into society. These losses may have long-term implications, especially if they lead to a 
breach of skills related to professional activities." [8]

Of course, the global financial crisis has had a negative impact on lives of all people in the Russian Federation, but it should be recognized that most of all it affected the most disadvantaged ones. "In the face of economic crisis all people were vulnerable, but those ones with disabilities were again among the most vulnerable", - said Valery Seleznev [9].

As a result of cuts in public forms of support employment of persons with disabilities in the recent years have seen a sharp decline in the number of employed people with disabilities - both in opened and in closed labor markets. This is particularly reflected in the specialized enterprises employing disabled persons, as they were most dependent on the level of state support. [7] All these factors to some extent contribute to the deterioration of the labor market of disabled people in Russia, but the main reason of poor performance of graduates with disabilities in the Russian labor market, in our view, is the lack of general psychological and vocational training for specialists with disabilities, defining a third group of factors.

Thus, a fundamental impact on the employment of persons with disabilities has a form of training. There is a significant difference in the rate of employment of graduates of specialized and nonspecialized high schools. Possibility to find a job is higher for those who have graduated from a university. For example, almost all graduates with disabilities of Moscow State Technical University (which implements a continuous education system for deaf students) are successfully employed. [10]

At the same time graduates of specialized schools often remain at work in the same institution, where they graduated from, or go to work to schools from which they came to university. [11] The reason is low demand for those people in the labor market. It is almost impossible to find a job within their professional area. That's why they have to work in highly specialized institutions with internal, closed, and non-competitive (with respect to open and external) labor markets for people with disabilities.

It happens for a number of reasons [12]: Firstly, after the completion of education in specialized institutions graduates with disabilities are often faced with serious problems of adaptation to reality. Creating special conditions for education of persons with disabilities, and satisfying their needs for medical and educational services, specialized institutions do not take into account changing external environment, need for active interaction with the external environment, reinforcing segregation and poor social integration of people with disabilities. It promotes inefficient inclusion of persons with disabilities into human society, limiting their life chances and possibility of further employment in their field. Finding a job for these people is not an easy task.

Secondly, universities mostly do not conduct their own scientific work with disabled students and, therefore, there is no interaction with the organizations that might be interested in recruiting students and graduates with disabilities as their potential employees. But you can evaluate quality of disabled persons' qualification only after networking.

Thirdly, employment of persons with disabilities is negatively influenced by prejudice of employers against disabled workers, specific nature of their diplomas of education.

Low level of professional qualification acquired in the walls of a higher educational institution impedes full professional integration of disabled people, which leads to an underestimation of competences of disabled people by Rus- 
sian employers. Many of Russian researchers share this opinion, stating that as a result of current practice of training and employment of persons with disabilities two worlds are being artificially created: the closed world of disabled people and the world of healthy people for whom doors are opened to every office. Moreover, there is an opinion among the experts that these two worlds will never meet.

Without the ability to be competitive in today's job market, dynamically evolving as innovative emerging smart economy, chance of disabled people for a good job as well as chances for complete integration into society are closed to zero.

\subsection{Implication of inclusive educa- tion on educational services' perfor- mance}

Currently inclusive education is considered as one of the most effective ways to address the problem of education for people with disabilities. Article 24 of the UN Convention on the Rights of Disabled People runs as follows:

"With a view to realizing this right (right to education - the author's note) without discrimination and on the basis of equal opportunity, States Parties shall ensure an inclusive education system at all levels and lifelong learning directed to:

a. The full development of human potential and sense of dignity and selfworth, and the strengthening of respect for human rights, fundamental freedoms and human diversity;

b. The development by people with disabilities of their personality, talents and creativity, as well as their mental and physical abilities, to their fullest potential;

Enabling people with disabilities to participate effectively in a free society"
Competitiveness development of people with disabilities with further integration into open labor markets should be started from the first days of admission to higher education by deep psychological inclusion of students with disabilities in the future professional environment. Psychological and professional training programs of disabled people are organically linked and, at the end of high school studies they form a coherent professional qualification of graduates with disabilities.

\section{Conclusion}

Inclusive education contributes to the following set of advantages:

- It is suitable for all students - not only with disabilities;

- All students have equal access to the educational process;

- All students have equal opportunities for establishing and developing important social ties;

- It is carried out an effective educational process based on the specially designed programs;

- Teachers involved in the educational process use techniques that facilitate incorporation of students with disabilities in a single social student environment and educational process;

- Educational programs take into account needs of every student;

- Involved workers have a positive attitude and are aware of their obligations;

- Adaptation is the least intrusive and does not encourage development of stereotypes;

- Activities are aimed at the inclusion of students, but are quite difficult for them;

- Individual assistance does not isolate students;

- There are possibilities for generalization, transferring, and extending the acquired knowledge; 
- There are possibilities for development of personal, creative and academic abilities;

- There is a development of individual and group work skills.

When educating people with disabilities, the particular emphasis should be put to ensure that any disabled person in accordance with his disease and capabilities is competitive on the labor market, considers the director of the Department of Health and Social Development Minister Olga Samarina.

Meanwhile, the result of an inclusive education is a graduate - person with disabilities who possesses such a set of professional skills that in the time of knowledge economy makes him competitive and in demand. That is aligned with the goals of Russian Higher Education and ranks inclusive education among the first places in education for people with disabilities. This in turn has a very positive effect on economic efficiency of education service as a whole, on GDP indicators as well as on competitiveness of national economy.

\section{References}

[1] Smolin Oleg, Education of persons with disabilities: ideology, technologies, legislation, http://www.smolin.ru/actual/public/20 08-06-26.htm

[2] Pechenkin V., Zaytsev D., Problems of education at disabled persons' glance, Social studies, 2008, vol. 3

[3] Speech by President of the AllRussian Society of Disabled People, deputy of the State Duma of the Russian Federation A. LomakinRumyantsev http://www.voi.ru/ documents.asp?view $=1 \&$ vid $=1085$

[4] Yarskaya-Smirnova E., Romanov P., Affordability problems of education for persons with disabilities, Social studies, 2005, vol. 10
[5] Convention on the Rights of Persons with Disabilities / Resolution A/61/611, adopted by UN General Assembly on January 24, 2007

[6] T. Golikova http://www.minzdravsoc. $\mathrm{ru} / \mathrm{social} /$ invalid-defence/49

[7]Russia is on the way to equal opportunities, M.: Vesy mir, 17 p., 2009.

[8]Problems of disability and its development, World Bank, http://go.worldbank.org/HL5HR03

[9] V. Seleznev, People with disabilities are among the most vulnerable categories of society at the times of global crisis, http://www.worldtoday.ru/ alltoday/release.html.

[10] The Number of Students with Disabilities Has Increased in the Russian Federation // URL: http://www.prostranstvo.ru /news /news/show/1070372763.htm

[11] From Virtual Life into Real One. Website of the Comission on Church Social Activities under the Diocesan Council of Moscow // http://www.miloserdie.ru/index.php?s $\mathrm{s}=4 \& \mathrm{~s}=19 \& \mathrm{id}=8052$

[12] James Lesko's report at the International Conference "Development of inclusive schools in Russia" "Inclusive school communities: Strategies for Success" 